\title{
ENFRENTAMENTO DO CRIME ORGANIZADO POR MEIO DA DELAÇÃO
} PREMIADA

\author{
Aricio Vieira Da Silva* \\ Danilo Marques Borges**
}

Resumo: O escopo deste estudo consiste na análise do instituto da Delação Premiada como instrumento de combate ao crime organizado diante da insegurança pública que assola a sociedade brasileira. O Estado brasileiro, a exemplo da Itália e Estados Unidos, busca através da traição benéfica, oferecer diminuição da pena ou até mesmo com o perdão judicial, enfrentar a difícil missão de extirpar do território nacional as organizações criminosas. Tratase de uma pesquisa bibliográfica, a qual fez uso de diversas leituras sobre a temática, tais como em artigos, teses, revistas especializadas no Direito, dentre outras fontes. Utilizando método exploratório e qualitativo.

Palavras-chave: Estado Brasileiro; Diminuição de Pena; Organização Criminosa; Colaboração Premiada; Eficácia.

\section{FACING CRIME ORGANIZED THROUGH AWARD DELLA}

Abstract: The scope of this study consists of the analysis of the Institute of Awarded Delight as an instrument to combat organized crime in the face of public insecurity that plagues Brazilian society. The Brazilian State, like Italy and the United States, seeks through charitable betrayal, to offer a reduction in punishment, or even with judicial forgiveness, to face the difficult task of extirpating criminal organizations from the national territory. It is a bibliographical research, which has made use of several readings on the subject, such as in articles, theses, specialized magazines in the Law, among other sources. Using exploratory and qualitative method.

Keywords: Brazilian State; Reduction of Penalty; Criminal Organization; Award Winning Collaboration; Efficiency.

\footnotetext{
* Mestre em Direito, Relações Internacionais e Desenvolvimento pela PUC de Goiás (2010). Doutorando em Direito pela Universidade do Vale dos Sinos (UNISINOS), servidor efetivo do Instituto Federal de Educação, Ciência e Tecnologia Goiano, Campus Rio Verde Goiás e Professor Adjunto I da Universidade de Rio Verde Goiás (UniRV), e Advogado.

** Mestre em Direito, Relações Internacionais e Desenvolvimento pela PUC de Goiás (2015). Doutorando em Direito pela Universidade do Vale dos Sinos (UNISINOS), Professor Adjunto I da Universidade de Rio Verde Goiás (UniRV), e Advogado.
} 


\section{INTRODUÇÃO}

Sem dúvida alguma a criminalidade vem aumentando de forma desordenada aumentando no Brasil, deixando a sociedade cada vez mais aterrorizada e, essa triste realidade tem feito com que os legisladores busquem mecanismos jurídicos que sejam capazes de banir, de maneira rápida e eficaz, as atrocidades cometidas pelos criminosos e pelas organizações criminosas.

O objeto do presente estudo consiste em demonstrar o que venha a ser organização criminosa e se a delação premiada tem sido eficaz no combate desta prática criminosa nos dias atuais.

Sabe-se que, desde os primórdios das sociedades os criminosos se associam em grupos com a finalidade de praticar crimes e auferir lucros no âmbito da criminalidade. $\mathrm{O}$ fortalecimento desses grupos se deu com o surgimento das máfias ítalo-americanas e orientais, estimulando-se a criação de máfias também no Brasil. Esses grupos possuíam um complexo modus operandi, altamente avançados para a época em que viviam.

O Estado brasileiro tem enfrentado uma árdua tarefa no combate ao crime organizado, grupos que se tornam cada vez mais ousados, violentos, bem armados e estruturados, exigindo do Estado mecanismos jurídicos mais eficazes na investigação, na coleta de dados e na obtenção de provas robustas capazes de comprovar até mesmo a existência da organização criminosa e obter provas dos ilícios penais por ela praticados.

As organizações criminosas movimentam quantias financeiras de cifras astronômicas no planeta e operam em todos os lugares do mundo. Com o advento da globalização, no século XXI, se estreitaram a interconexão internacional, proporcionando uma estruturação moderna da criminalidade.

No estudo das organizações criminosas, verifica-se que cada nação tem um submundo, mas, na economia global de hoje, um território global paralelo de gangues surgiu onde as organizações criminosas transnacionais controlam mais poder econômico do que alguns estados como nação.

A repressão de crimes cometidos por grupos organizados por muito tempo restou carente de regulamentação, passando por diversas leis e convenção, principalmente a Convenção de Palermo, até se chegar a Lei 12.850/13, que regulamenta as organizações criminosas, as formas de investigações e conceitos relacionados às organizações. 
No Brasil atualmente, existem diversos grupos criminosos que ganham destaque pela sua atuação, a maioria deles comandados de dentro dos presídios. Entre os principais estão: o Comando Vermelho, o Primeiro Comando da Capital (PCC) e o Terceiro Comando que posteriormente passa a ser definido como A.D.A (Amigos dos Amigos).

A delação premiada ou colaboração premiada, consiste na confissão pelo acusado da prática delituosa que lhe é imputada e, ao mesmo tempo auxilia a justiça revelando também quais foram seus comparas, contribuindo na elucidação do crime e sobretudo, oferecendo elementos para novas investigações capazes de obter sucesso no combate ao crime, em especial ao crime organizado.

Aquele que oferecer às investigações informações relevantes na identificação da organização, forma de execução das tarefas, estrutura organizacional, e ainda possíveis crimes que irão acontecer, bem como informações sobre vítimas que possam a vir ser resgatadas, receberá benefícios, tais como redução da pena, perdão judicial, progressão de regime, a depender da relevância das informações para a persecução criminal.

A aplicação do prêmio ao colaborador, de acordo com o princípio da proporcionalidade, levará em conta o momento em que são ofertadas as informações, bem como a importância e necessidade daquelas informações à persecução penal, sendo que, quanto maior a colaboração para derrubar o grupo criminoso, maior será o prêmio recebido.

Desta forma, será feito no presente estudo uma breve análise histórica e jurídica das organizações criminosas no nosso país, bem como, estudo da origem, definição, assento legal, requisitos e procedimento da Delação Premiada. Ao final verificará se a colaboração ou delação premiada tem se mostrado eficiente no combate ao crime organizado no território nacional.

\section{BREVE HISTÓRICO E EVOLUÇÃO LEGISLATIVA DAS ORGANIZAÇÕES CRIMINOSAS NO BRASIL}

Fazendo referência a origem do crime organizado, assim comenta Southwell (2013) que, embora as origens das primeiras "seitas" das quais surgiram grupos italianos do crime organizado possam remontar a centenas de anos atrás, a ligação direta entre elas e a Camorra, a ‘Ndrangheta e as famílias criminosas da máfia siciliana remonta provavelmente a não antes de 1810. No Brasil, os primeiros registros se denotam do movimentos dos cangaceiros na região

Rev. de Criminologias e Politicas Criminais | e-ISSN: 2526-0065 | Porto Alegre | v. 4 | n. 2 | p. 102 - 118 | Jul/Dez. 2018 
nordeste com enfrentamento ao Coronelismo que vigorava no final do século XIX e no começo do Século XX.

Virgulino Ferreira da Silva, conhecido como Lampião (1897-1938), foi o grande líder dos cangaceiros que em comitiva viajava pelo semiárido nordestino saqueando fazendas dos coronéis, vilas e pequenas cidades, apossando-se das riquezas, utilizando para tais crimes violentos, ameaças e sequestros de pessoas importantes, visando à extorsão para obtenção de recursos para sustentar seu bando. Através da postura que tinham os jagunços e capangas dos grandes fazendeiros no Sertão Nordestino, o que ficou conhecido com cangaço. Havia uma organização hierarquicamente organizada em que os cangaceiros agiam com o apoio dos grandes fazendeiros, e também de policiais corruptos, que lhes forneiam munições e armamentos (SILVA, 2017).

No decorrer do tempo se desenvolveu uma pratica ilícita que ficou conhecida como “jogo do bicho", que reunia um grupo de pessoas com a finalidade de cometer o ilícito penal. Esse jogo de azar foi popularizado e patrocinado por grupos organizados, através de policiais e políticos corruptos.

Contudo, as organizações mais perigosas do Brasil, tiveram inicio nos anos 70 e 80 , dentro das prisões do Rio de Janeiro, as quais ficaram conhecidas como: Comando Vermelho, que contava com a organização tanto de presos comuns como de presos políticos; a Falange Vermelha, que foi criada por especialistas em roubos de banco; o Terceiro Comando (que posteriormente virou o ADA - Amigo dos amigos) e o Terceiro Comando Puro, que extinguiu o Terceiro Comando, com a morte de seu líder, e grupos para-policiais, que atuavam em favelas cariocas, com o fim de expulsar as facções criminosas locais.

Observa-se com o desenrolar histórico, que o Brasil demorou bastante tempo para regularizar a situação legislativa que tratasse desses grupos criminosos.

Foi a partir do surgimento de notícias sobre casos de tráficos de pessoas e de drogas, e também execuções, lavagem de dinheiro, corrupções, cometidos por grupos de pessoas, nitidamente organizados de forma hierárquica em uma estrutura ordenada, com divisão de tarefas e a finalidade de obter vantagens de qualquer natureza, que o legislador foi forçado a criar uma Lei, de forma rápida, com o objetivo de denominar essas grupos criminosos. Assim foi criada a Lei ${ }^{\circ}$ 9.034/95, segundo Masson e Marçal (2017), que foi bastante omissa em muitos pontos, pois não trouxe um conceito de crime organizado, não definiu os dispositivos de investigação, tais como: ação controlada, formas de infiltração, delação premiada. 
Ante a essas omissões, os juristas utilizavam como definição de organizações criminosas, o conceito adotado na Convenção de Palermo, sobre a criminalidade transnacional (posteriormente ratificado pelo Brasil, através do Decreto $\mathrm{n}^{\circ}$ 5.015/2004), que definia grupo criminoso como sendo, um grupo de três ou mais pessoas, organizado, que existisse há algum tempo e que atuasse com o propósito de cometer uma ou mais infrações penais e que tivesse a intenção de obterem, direta ou indiretamente, uma vantagem econômica ou outro benefício material (SILVA, 2017).

A partir daí, STJ (HC 77.771-SP) e STF (HC 96.007) passaram a utilizar o conceito adotado pela Convenção de Palermo, para se referir às organizações criminosas.

Porém, tal atitude dos tribunais superiores foi bastante questionada pelos juristas, principalmente Luiz Flávio Gomes (2009) que defendia que “definições dadas pelas convenções ou tratados internacionais jamais valem para reger nossas relações com o Direito penal interno em razão da exigência do princípio da democracia (ou garantia da lex populi)", pois nenhum documento internacional que trate de definir crimes e cominar penas pode ser fonte normativa direta, aplicada ao Direito interno brasileiro. E ressalvou ainda que o tratado de Palermo não tinha nenhum valor normativo que fosse suficiente para conceituar e delimitar as organizações criminosas.

Esses questionamentos obrigaram o legislador a criar uma nova lei com o objetivo de regulamentar as formas de criminalidade. A Lei 12.694/12, foi criada às pressas, a fim de atender o clamor social. Criou-se com a nova Lei, um colegiado para julgamento de crimes praticados por grupos criminosos, criando-se também um conceito para organizações criminosas, pela primeira vez no Brasil. Entretanto, esta Lei foi omissa quanto às formas de investigação, continuando estas sendo vagamente definidas pela lei anterior.

Pouco tempo depois, em 02 de agosto de 2013, foi criada a Lei 12.850, que ficou conhecida como Lei das Organizações Criminosas. Esta nova Lei revogou expressamente a Lei 9.034/95 e parte conceitual da Lei 12.694/12, pois esta última definia o colegiado para julgamento, o que não veio definido na nova lei (MASSON; MARÇAL, 2017).

Deste modo, com a nova Lei, as organizações criminosas foram tratadas como “novatio legis" incriminadora, tendo a paz pública como bem jurídico tutelado, mas não teve caráter retroativo, não alcançando assim os fatos esgotados antes da vigência da nova ordem legal.

Rev. de Criminologias e Politicas Criminais | e-ISSN: 2526-0065 | Porto Alegre | v. 4 | n. 2 | p. 102 - 118 | Jul/Dez. 2018 


\section{COLABORAÇÃO PREMIADA OU DELAÇÃO PREMIADA}

\subsection{Origem}

A colaboração premiada trata-se de um instituto do Direito Penal que apresenta vestígios desde a Idade Média, porém, conquistou maior destaque após a sofisticação da criminalidade.

Esse instituto se desenvolveu diante das dificuldades encontradas ao longo dos anos para se punir os crimes que eram praticados em concurso de agentes (PARANAGUÁ, 2013).

Como dito, os primeiros indícios da colaboração premiada são visualizados durante o período da Inquisição, na Idade Média, no qual se costumava distinguir o valor da confissão de acordo com a forma em que ela acontecia. Por exemplo, se o corréu confessava de forma espontânea, não tinha credibilidade sua confissão, diferentemente era tratada a sua confissão através da tortura, que era mais bem valorizada (PARANAGUÁ, 2013).

A delação premiada tem sua origem, segundo Jesus (2005):

Remonta às Ordenações Filipinas, cuja parte criminal, consoante do Livro V, vigorou de janeiro de 1603 até a entrada em vigor do Código Criminal de 1830. O Título VI do "Código Filipino", que definia o crime de "Lesa Magestade" (sic), tratava da "delação premiada" no item 12; o Título CXVI, por sua vez cuidava especificamente do tema, sob a rubrica "Como se perdoará aos malfeitores que derem outros à prisão" e tinha abrangência, inclusive, para premiar, com perdão, criminosos delatores e delitos alheios

A colaboração premiada foi ganhando força através da necessidade do Estado em conter o crime cometido em concurso de pessoas, e em acompanhar a evolução das organizações criminosas. Esse instituto traz uma solução para suprir a ineficiência estatal e também como uma forma de apresentar resultados práticos à sociedade (PARANAGUÁ, 2013).

Mesmo estando presente em todos esses momentos históricos, a colaboração premiada passou a integrar o ordenamento jurídico brasileiro a partir da criação da Lei $n^{\circ}$ 8.072/90- Lei dos Crimes Hediondos - que trouxe uma forma efetiva de acabar com as quadrilhas e bandos que se formam com a finalidade de praticar crimes considerados hediondos. A partir daí, a colaboração premiada passou a integrar várias outras legislações. (PARANAGUÁ, 2013).

Sobre o tema, Masson e Marçal (2016, p. 76), ensinam: 
A evolução legislativa sobre o instituto denota o quanto veio sendo lapidada a colaboração premiada entre nós. Em sua gênese, não se previa a forma como se efetivaria na práxis a "delação"; não havia regras visando à proteção do colaborador; poucos eram os prêmios legais. Por outro lado, a Lei 12.850/2013 alterou sensivelmente esse quadro. Surgiram regras claras para a celebração do acordo; o magistrado foi afastado da negociação; exigiu-se requerimento e homologação judicial; foram previstos direitos ao colaborador; tipificou-se como crime a revelação indevida de sua identidade; surgiram novos prêmios (v.g., "acordo de não denunciar" ou "acordo de imunidade"). A partir da Lei do Crime Organizado, portanto, é improcedente a conceituação do instituto com base, exclusivamente, na delação dos comparsas formulada pelo colaborador, haja vista que a benesse legal pode ser conquistada também quando forem atingidos outros objetivos, tais como: (a) a prevenção de infrações penais decorrentes das atividades da organização criminosa, (b) a recuperação total ou parcial do produto ou do proveito das infrações penais praticadas pela organização criminosa e (c) a localização de eventual vítima com a sua integridade física preservada.

Em consequência da fraqueza do Estado em combater de modo eficiente a criminalidade que se desenvolveu em âmbito nacional, a delação premiada cresceu, se desenvolveu de modo significativo buscando mecanismos jurídicos eficientes no combate ao crime organizado.

\subsection{Definição e Aporte Legal}

Delação vem do latim delatione, que significa ato de delatar, denúncia, revelação, manifestação, amostra (FERREIRA, 2005), num sentido jurídico, delação equivale ao ato de denunciar alguém pela prática de um crime, ou seja, o agente que esta sendo acusado de uma infração penal, além de confessar a prática delituosa, revela os outros agentes que perpetraram a conduta delituosa.

Assim, tem-se como conceito de colaborar a prática de auxiliar, contribuir. Já o termo "premiada" expressa o sentido de recompensa, vantagem, prêmio por contribuir em algo.

Nesse sentido, Nucci (2015, p. 39) conceitua o instituto da colaboração premiada:

Embora a lei utilize a expressão colaboração premiada, cuida-se, na verdade, da delação premiada. $\mathrm{O}$ instituto, tal como disposto em lei, não se destina a qualquer espécie de cooperação de investigado ou acusado, mas àquela na qual se descobrem dados desconhecidos quanto autoria ou materialidade da infração penal. Por isso, trata-se de autêntica delação, no perfeito sentido de acusar ou denunciar alguém - vulgarmente, o dedurismo.

Rev. de Criminologias e Politicas Criminais | e-ISSN: 2526-0065 | Porto Alegre | v. 4 | n. 2 | p. 102 - 118 | Jul/Dez. 2018 
A colaboração premiada ou delação premiada, como passa a ser denominada após a edição da Lei $12.850 / 2013$, consiste na possibilidade que um indivíduo que é preso, por participar de crimes orquestrados por organizações criminosas, colabore com a justiça na investigação dos demais membros da organização, fornecendo informações primordiais, tais como: nomes, locais, gravações, contatos e todo tipo de dado que auxilie a desarticular, investigar e processar o crime em questão. Em troca, é oferecido ao delator, alguma vantagem, como uma diminuição de sua pena (VASCONCELLOS, 2017).

O instituto da colaboração premiada está previsto no artigo $4^{\circ}$ e incisos, da Lei 12.850/13. Senão vejamos:

Art. 4ㅇ $\mathrm{O}$ juiz poderá, a requerimento das partes, conceder o perdão judicial, reduzir em até $2 / 3$ (dois terços) a pena privativa de liberdade ou substituí-la por restritiva de direitos daquele que tenha colaborado efetiva $\mathrm{e}$ voluntariamente com a investigação e com o processo criminal, desde que dessa colaboração advenha um ou mais dos seguintes resultados:

I - a identificação dos demais coautores e partícipes da organização criminosa e das infrações penais por eles praticadas;

II - a revelação da estrutura hierárquica e da divisão de tarefas da organização criminosa;

III - a prevenção de infrações penais decorrentes das atividades da organização criminosa;

IV - a recuperação total ou parcial do produto ou do proveito das infrações penais praticadas pela organização criminosa;

V - a localização de eventual vítima com a sua integridade física preservada.

De acordo com a previsão normativa da Lei 12.850/2013 (art. 3. ${ }^{\circ}$ ), a colaboração premiada tem a natureza jurídica de meio de obtenção da prova, materializado em um "acordo" reduzido a "termo" para devida homologação judicial. A colaboração premiada é, pois, um "negócio jurídico processual” voltado para a obtenção de prova, e não um meio de prova propriamente dito (MASSON; MARÇAL, 2016, p. 10).

Sobre a natureza jurídica desse instituto, Masson e Marçal (2016, p.78) ensina:

Pela literalidade da Lei do Crime Organizado, a colaboração premiada tem sua própria natureza jurídica (negócio jurídico processual voltado para a obtenção da prova), que não se confunde com a natureza do prêmio legal eventualmente aplicado, razão pela qual discordamos do entendimento segundo o qual "a delação premiada, a depender das condicionantes estabelecidas na norma, assume a natureza jurídica de perdão judicial, implicando a extinção da punibilidade, ou de causa de diminuição de pena".

Rev. de Criminologias e Politicas Criminais | e-ISSN: 2526-0065 | Porto Alegre | v. 4 | n. 2 | p. 102 - 118 | Jul/Dez. 2018 
Esse entendimento peca por confundir a natureza da colaboração (que não pode ser variável) com a dos prêmios.

Vejamos a decisão dada pelo Relator Dias Toffoli (HC 127.483/PR, julgado em 27/08/2015), in ipsis litteris:

\begin{abstract}
A colaboração premiada é um negócio jurídico processual, uma vez que, além de ser qualificada expressamente pela lei como "meio de obtenção de prova", seu objeto é a cooperação do imputado para a investigação e para o processo criminal, atividade de natureza processual, ainda que se agregue a esse negócio jurídico o efeito substancial (de direito material) concernente à sanção premial a ser atribuída a essa colaboração. Dito de outro modo, embora a colaboração premiada tenha repercussão no direito penal material (ao estabelecer as sanções premiais a que fará jus o imputado-colaborador, se resultar exitosa sua cooperação), ela se destina precipuamente a produzir efeitos no âmbito do processo penal (BRASIL, 2015).
\end{abstract}

O julgado ratificou a opinião exprimida por Mason e Marçal, e confirmou que "a colaboração premiada seria meio de obtenção de prova, destinado à aquisição de elementos dotados de capacidade probatória", e não um "meio de prova propriamente dito". Tornando assentada a ideia de que o acordo de colaboração não se confunde com os depoimentos prestados pelo agente colaborador.

Dentre os relevantes efeitos processuais do acordo de colaboração, destacam-se os previstos no art. $4^{\circ}$ da Lei $\mathrm{n}^{\circ}$ 12.850/13: I) "o prazo para oferecimento de denúncia ou o processo, relativos ao colaborador, poderá ser suspenso por até 6 (seis) meses, prorrogáveis por igual período, até que sejam cumpridas as medidas de colaboração, suspendendo-se o respectivo prazo prescricional” ( $\left(3^{\circ}\right)$; II) “o Ministério Público poderá deixar de oferecer denúncia se o colaborador não for o líder da organização criminosa ou for o primeiro a prestar efetiva colaboração $\left(\S 4^{\circ}\right)$; e III) "nos depoimentos que prestar, o colaborador renunciará, na presença de seu defensor, ao direito ao silêncio e estará sujeito ao compromisso legal de dizer a verdade" $(\S 14)$.

Além disso, nos termos do art. $5^{\circ}$ da Lei $n^{\circ} 12.850 / 13$, o acordo de colaboração judicialmente homologado confere ao colaborador o direito de: a) "usufruir das medidas de proteção previstas na legislação específica"; b) "ter nome, qualificação, imagem e demais informações pessoais preservados"; c) "ser conduzido, em juízo, separadamente dos demais coautores e partícipes", e d) "participar das audiências sem contato visual com os outros acusados" (VASCONCELLOS, 2017, p. 150). 


\title{
3.3 Requisitos
}

Os requisitos para aplicação da vantagem ao delator, estão previstos no artigo $4^{\circ}$, da

Lei 12.850/13:

\begin{abstract}
Art. 4o O juiz poderá, a requerimento das partes, conceder o perdão judicial, reduzir em até $2 / 3$ (dois terços) a pena privativa de liberdade ou substituí-la por restritiva de direitos daquele que tenha colaborado efetiva e voluntariamente com a investigação e com o processo criminal, desde que dessa colaboração advenha um ou mais dos seguintes resultados:

I - a identificação dos demais coautores e partícipes da organização criminosa e das infrações penais por eles praticadas;

II - a revelação da estrutura hierárquica e da divisão de tarefas da organização criminosa;

III - a prevenção de infrações penais decorrentes das atividades da organização criminosa;

IV - a recuperação total ou parcial do produto ou do proveito das infrações penais praticadas pela organização criminosa;

$\mathrm{V}$ - a localização de eventual vítima com a sua integridade física preservada. (BRASIL, 2013).
\end{abstract}

De acordo com Nucci (2015, p. 42), "Os requisitos para a colaboração premiada são cumulativo-alternativos, da seguinte forma: em cumulação os previstos nas alíneas $a$ e $b$, associados a um dos demais, previstos nas alíneas $c, d, e, f$ e $g$ ".

Por sua vez, seguindo o preceito legal previsto na Lei 12.850/2013, só pode ser aplicada delação premiada de forma exclusiva em crime que envolva organização criminosa. (MOSSIN H; MOSSIN J, 2018).

\subsection{Procedimento}

O instituto da colaboração premiada pode ocorrer tanto na fase investigatória como na fase processual.

Durante o inquérito policial, a colaboração premiada, chamada também de colaboração inicial, pode-se dar da seguinte forma:

a) o delegado, nos autos do inquérito policial, com a manifestação do Ministério Público, representa pela aplicação do prêmio máximo, que é o perdão judicial, causador da extinção da punibilidade, cessando-se a persecução penal; b) o delegado, nos autos do inquérito, representa e, antes de seguir ao juiz, passa pelo Ministério Público para colher sua manifestação, 
seguindo-se o pleito de perdão judicial; c) o Ministério Público, valendo-se do inquérito, requer ao magistrado a aplicação do perdão judicial. Em suma, delegado e promotor, juntos, representam pelo perdão; delegado representa, promotor é ouvido e segue ao juiz; promotor requer diretamente ao juiz (NUCCI, 2015, p. 44).

O juiz não pode conceder o perdão de judicial de ofício, na fase investigatória, deve o delegado de policia representar requerendo a colaboração premiada ao investigado, juntamente com a concordância do MP, e cabe ao juiz apenas homologá-lo, se cumprir todos os requisitos legais. "Vale ressaltar que o requerimento do Ministério Público pela aplicação do perdão pode dar-se a qualquer tempo (art. $4 .^{\circ}, \S 2 .^{\circ}$ ), do período que segue da investigação ao processo, até a sentença.” (MPF, 2011, p. 44).

Após o requerimento da autoridade policial, juntamente com a anuência do Ministério Público, caberá o "sobrestamento do oferecimento da denúncia, por até 6 meses, prorrogáveis por igual período, até que sejam cumpridas as medidas de colaboração", ou seja, até que o colaborador tenha efetivamente ajudado para que a autoridade policial, bem como o Ministério Público tenham elementos necessários para comprovar a veracidade dos fatos delatados, a identificação dos coautores ou partícipes, a noção da estrutura hierárquica da organização criminosa, bem como a atuação de cada um em sua determinada função, a recuperação do proveito do crime ou de possíveis vítimas. A depender da importância que a delação trouxe à investigação e também para o oferecimento de uma denúncia bem elaborada, a acusação pode deixar de denunciar o colaborador (MPF, 2014, p. 14).

Ademais no que tange o prazo prescricional, o artigo $4^{\circ}, \S 3^{\circ}$ da Lei $12.850 / 13$, prevê que ficará suspenso o prazo enquanto correr o prazo de suspensão do oferecimento da denúncia, podendo ocorrer a prorrogação da suspensão do prazo prescricional, com a devida autorização do juiz competente.

A colaboração pode ocorrer também durante a fase judicial, nesta é chamada de colaboração intercorrente.

Nesta fase o acusado deverá colaborar não apenas apresentando a sua confissão relativo ao crime e a sua participação na organização criminosa, mas sim informando os detalhes pertinentes para a identificação dos demais integrantes do grupo, bem como os crimes por eles praticados (MPF, 2014).

O juiz não participa do acordo, cabendo a ele somente suspender a instrução processual, em caso de celebração de acordo entre o acusado e o Ministério Público. Este por 
sua vez, não tem obrigação de aceitar ou propor o acordo caso constate que o mesmo não é favorável para o processo. Caso o MP opte por não aceitar ou não propor o acordo de colaboração, a ação penal correrá normalmente, sem que ocorra a suspensão ou possível desmembramento. Caso o acordo seja homologado, "o juiz irá colher a confirmação das revelações no âmbito judicial e submeter a prova ao contraditório.” (MPF, 2014, p. 15-16).

Fala-se também, em colaboração tardia, isto é, aquela que ocorre após a sentença. Neste caso, aplicar-se-á as mesmas regras da colaboração inicial e intercorrente, mudando-se apenas o julgador, que será o Tribunal a quem competir o julgamento do recurso ou pelo Juiz da vara de execução penal (MPF, 2014).

No acordo de colaboração premiada, o juiz atuará apenas para homologar o acordo e aplicar os benefícios que serão concedidos ao acusado colaborador. Esses benefícios estão previstos no artigo $4^{\circ}$, caput, da Lei $12.850 / 13$. Vejamos:

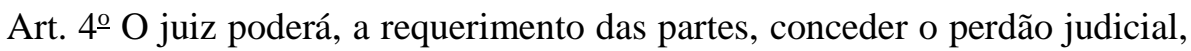
reduzir em até $2 / 3$ (dois terços) a pena privativa de liberdade ou substituí-la por restritiva de direitos daquele que tenha colaborado efetiva e voluntariamente com a investigação e com o processo criminal, desde que dessa colaboração advenha um ou mais dos seguintes resultados: [...]. (BRASIL, 2013).

O maior benefício que se tem com a colaboração premiada é o perdão judicial, ou seja, a renúncia do Estado à pretensão punitiva.

Vale ressaltar ainda, que após a sentença condenatória, caso haja a colaboração premiada, não poderá ser aplicado o perdão judicial, cabendo apenas a aplicação de redução da pena até a metade (art. 4. ${ }^{\circ}, \S 5^{\circ}$, Lei 12.850/2013), ou a progressão de regime, mesmo que ausentes os requisitos objetivos, ou seja, tempo mínimo no regime anterior.

Essa inovação é um sensível incremento à colaboração premiada, porquanto aposta na falta de disposição do sentenciado de arcar sozinho com o ônus da condenação, decidindo delatar os comparsas restantes (SANTOS, 2017).

Assim como possui direitos, o colaborador possui obrigações em relação ao acordo prestado. Assim deverá o colaborador em seus depoimentos:

prestar o compromisso de: (a) renunciar, na presença do defensor, ao direito ao silêncio; (b) dizer a verdade, na forma do $§ 14$ do artigo $4 .^{\circ}$ da Lei 12.850/13. A razão de ser do instituto é a busca de provas internas à estrutura delituosa, em tese rígida e compartimentada, valendo-se de pessoa com 
conhecimento privilegiado exatamente pela condição de ter atuado nessa associação criminosa, ou em fatos delituosos por ela cometidos. A confissão que não for relevante e eficaz, todavia, não servirá para a concessão do benefício, não indo além da atenuante prevista no artigo 65, inciso III, alínea “d”, do Código Penal. (MPF, 2014, p. 16).

O prêmio ofertado ao colaborador poderá ser graduado, a depender da extensão e relevância dos elementos revelador por ele. "Deve haver uma proporção entre o grau de cooperação do agente e o quantum de prêmio a receber.” O juiz analisará ainda outros aspectos relevantes, como o fato de o colaborador comparecer em juízo e confirmar as suas declarações, devendo aceitar ser questionado pela defesa e órgãos auxiliares da persecução penal.

Haverá de se considerar também o que constou no compromisso prévio firmado entre o órgão da acusação e o colaborador, pois, ainda que o magistrado não se tenha vinculado ao conteúdo desse termo, o compromisso serve de referência importante da conduta do colaborador e na definição da dimensão do favor (MPF, 2014, p. 17).

Assim, "O juiz deve fundamentar o percentual de redução da pena aplicado" (MPF, 2014, p. 17).

\subsection{A Eficácia da Colaboração Premiada no combate ao Crime Organizado}

O crime organizado ganhou uma significativa evolução nos últimos anos. Hoje uma das maiores problemáticas enfrentadas no âmbito criminal se observa em descobrir quem são os integrantes da organização criminosa, como é a hierarquia exercida entre eles e qual função cada um exerce dentro do grupo criminoso. Principalmente, no que tange aos grandes chefes das organizações, tem sido uma tarefa de um enorme grau de dificuldade identificá-los.

A colaboração premiada tem sido uma importante arma no combate a este tipo de criminalidade, qual seja, o crime organizado. Essa modera técnica ajuda a fortalecer as investigações, uma vez que traça rumos aos quais a investigação deve seguir. Sem ela os investigadores (autoridade policial e Ministério Público) podem demorar um pouco mais de tempo para descobrirem provas que corroborem na persecução criminal. Assim, com a ajuda do colaborador em traçar os rumos que as investigações devem seguir, a polícia tem uma economia de anos de investigação, ganhando tempo e conseguindo derrubar a organização criminosa com mais rapidez (SILVA, 2016). 
O STF já se posicional favorável ao instituto da colaboração premiada, uma das mais importantes foi no julgamento da Ação Penal no 470/MG - 112, que ficou conhecida como "mensalão"1.

Para corroborar com o que foi explanado anteriormente, tem-se o e entendimento da ministra Rosa Weber do Supremo Tribunal Federal, citada por SILVA (2016) de que "o elemento ontológico da colaboração premiada não está na pessoa do colaborador e sim no pragmatismo, no interesse da persecução penal e na perspectiva de reduzir os danos causados pelos crimes que orientam a razão de ser da própria colaboração."

Assim, entende-se que a importância da colaboração premiada pode ser definida na utilidade em que se tem com o acordo que é celebrado com o colaborador e a utilidade que este venha a ter na persecução criminal (SILVA, 2016).

Outra benesse que esse instituto proporciona é no avanço do andamento dos processos criminal, retirando um pouco da sobrecarga que existem nas varas criminais deste país, que estão repletas de réus aguardando os seus julgamentos, esperando por meses ou até anos para conseguirem, o que compromete a garantia individual de cada um a ter um julgamento rápido, garantido pelo princípio da celeridade processual (SILVA, 2016).

Cumpre ressaltar que, a colaboração premiada sozinha não é suficiente para ensejar uma condenação criminal, ela deve ser analisada juntamente com outras provas produzidas durante a persecução penal. Assim, tem-se que a colaboração traçará de uma forma mais rápida o trabalho dos investigadores em buscarem por outros meios de prova a comprovação do que foi dito no acordo de colaboração.

Quando se fala em crime organizado ou organizações criminosas, fala-se em um modus operandi sofisticado, isto é, armamento de grande porte, um aparato de tecnologia que não é qualquer um que dispõe, relações com pessoas ligadas ao Estado, leia-se, indivíduos de grande influência no poder central do país, que facilitam a ação desses criminosos. Assim não é qualquer informação dada pelo colaborador que valerá um acordo de colaboração premiada, as informações repassadas por este devem ser eficazes no combate ao crime organizado (ANTÔNIO, 2015).

\footnotetext{
${ }^{1}$ Pelo voto do Ministro Luiz Fux, acompanhando a respeitável decisão do Ministro Relator Joaquim Barbosa, "frisou que a delação premiada é uma ferramenta importante para elucidação de crimes societários, tendo em vista a dificuldade de individualização concreta de autores e partícipes nesses delitos sofisticados (Lei 9.807/99, artigos 13 e 14). A respeito, citou precedente do STF (HC 99736/DF, DJe de 21.5.2010) no sentido de obstar ao delator a causa de diminuição de pena seria conduta desleal do Estado-juiz" (BRASIL, 2012).
} 
Desta forma, tem-se que a principal vantagem do uso da colaboração premiada é a ordem prática, uma vez que encontramos frente a uma:

\begin{abstract}
impossibilidade de se valer de outras provas previstas nas investigações em geral, por não terem a eficácia desejada, uma vez que os integrantes das facções criminosas estão sujeitos ao Código de Honra e a grande necessidade de desmantelar a criminalidade organizada que hoje tem descomunal parcela na violência em que se vive, e que deixa a sociedade amedrontada e acuada, como se fossem os cidadãos de bem os verdadeiros criminosos. (ANTÔNIO, 2015).
\end{abstract}

O medo de serem punidos pelas facções impedem as pessoas envolvidas com esses grupos (que não foram presas ou se submeteram a um acordo de colaboração premiada) denunciem os integrantes, a hierarquia existente entre eles e ainda os crimes cometidos por eles, o que dá um valor maior ao instituto da colaboração premiada como meio de combater o crime organizado (ANTÔNIO, 2015).

\title{
4 CONSIDERAÇÕES FINAIS
}

Para combater a criminalidade organizada o Estado não deve utilizar unicamente uma política criminal repressiva, com privação de direito, visando apenas punir com maior severidade, como exemplo, o que ocorreu na década de 90 com a Lei dos Crimes Hediondos (Lei 8.072/90) e não reduziu ou acabou com os crimes abrangidos pela referida norma.

O enfrentamento das organizações criminosas, cada dia mais avança em direção a um direito penal especial ou de exceção. A criminalidade organizada, por suas características peculiares, exige o emprego de meios especiais de investigação ou de obtenção de provas na sua apuração.

O estudo aqui realizado verificou que a legislação brasileira através da Lei 12.830/13, sem dúvida alguma trouxe algo inovador ao combate estatal do crime organizado: a delação ou colaboração premiada. A utilização deste instrumento tem sua relevância e utilidade no campo da persecução penal, visando ao combate destemido de organizações criminosas, o que é altamente salutar para os interesses da coletividade.

Considerando a ineficácia estatal em acabar com a macrocriminalidade, os propósitos das leis são os melhores possíveis, com a introdução de novos mecanismos em busca da paz 
social, segue-se uma nova tendência de política criminal para atender aos anseios e necessidades que emergem da sociedade.

A utilização de acordos de colaboração premiada em inquéritos e processos relacionados a desvios de recursos públicos demonstrou que o instituto da delação premiada tem demonstrado eficácia e traduzido em importante arma legal no enfrentamento ao crime organizado, sobretudo, "criminosos do colarinho branco"2.

Assim, a delação premiada, tornou-se um forte instrumento de auxílio do Estado no combate ao crime, apesar da polêmica que paria em torno dela, dada sua grande utilidade e o medo que impera perante a criminalidade crescente, ademais, seus aspectos positivos, superam os negativos, consoante ficou demonstrado.

\section{REFERÊNCIAS}

ANTÔNIO, Marcos. A delação premiada como método de combate ao crime organizado. 28 de outubro de 2015. Disponível em: <https://www.direitonet.com.br/artigos/exibir/9455/adelacao-premiada-como-metodo-de-combate-ao-crime-organizado>. Acesso em: 25 maio. 2018 .

BRASIL. Lei $n^{\circ} 12.85$, de 2 de agosto de 2013. Define organização criminosa e dispõe sobre a investigação criminal, os meios de obtenção da prova, infrações penais correlatas e o procedimento criminal; altera o Decreto-Lei nº 2.848, de 7 de dezembro de 1940 (Código Penal); revoga a Lei no 9.034, de 3 de maio de 1995; e dá outras providências. Diário Oficial da União. Brasília, DF, 2 de agosto de 2013. Disponível em: http://www.planalto.gov.br/ccivil_03/_ato2011-2014/2013/lei/112850.htm. Acesso em: 26 jul. 2018.

Supremo Tribunal Federal. Habeas Corpus n. 127. 483/PR, julgado em 27 de agosto de 2015. Paciente: Erton Medeiros Fonseca e co-atores relator do inquérito n. 5244 do Superior Tribunal de Justiça e Superintendência da Polícia Federal no Distrito Federal. Relator: Min. Dias Toffli. Brasília, DF, 27 de agosto de 2015. Disponível em: <http://redir.stf.jus.br/paginadorpub/paginador.jsp?docTP=TP\&docID=10199666 >. Acesso em: 26 jul. 2018.

Superior Tribunal de Justiça. Informativo no 0861. Primeira turma. 24.09. 2012. Disponível em: < http://www.stf.jus.br/arquivo/informativo/documento/informativo681.htm> Acesso em: 26 jul. 2018.

\footnotetext{
2 "São, em geral, crimes tipicamente econômicos ou tributários, relacionados à utilização de informações privilegiadas, fraudes, questões relativas à corrupção e pessoas das quais não se espera, via de regra, o cometimento de crimes". In DIREITOS. O que são os famosos crimes de colarinho branco?. Disponível em: https://direitosbrasil.com/o-que-sao-os-famosos-crimes-de-colarinho-branco/. Acesso em: 31 jul. 2018.
} 
DIREITOS. O que são os famosos crimes de colarinho branco?. Disponível em: https://direitosbrasil.com/o-que-sao-os-famosos-crimes-de-colarinho-branco/. Acesso em: 31 jul. 2018.

FERREIRA, Aurélio Buarque de Holanda. Dicionário Aurélio da Língua Portuguesa. 1a. ed. Editora: Positivo, 2005.

GOMES, Luiz Flávio. Definição de crime organizado e a Convenção de Palermo. 2009. Disponível em:<https://lfg.jusbrasil.com.br/noticias/1060739/definicao-de-crime-organizadoe-a-convencao-de-palermo>. Acesso em: 26 jul. 2018.

MASSON, C. MARÇAL, V. Crime organizado. 2. ed. rev., atual. e ampl. Rio de Janeiro: Forense; São Paulo: MÉTODO, 2016.

Crime organizado. 3. ed. rev., atual. e ampl. Rio de Janeiro: Forense, São Paulo: MÉTODO, 2017.

MOSSIN, H. A; MOSSIN. J. C. O. G. Delação Premiada: Aspectos Jurídicos. 3 ed. Leme: J. H. Mizuno, 2018.

MPF. Manual Colaboração Premiada. UNCCLA. Brasília, janeiro de 2014. Disponível em: $<$ http://www.mpf.mp.br/atuacao-tematica/sci/dados-da-atuacao/eventos-2/eventosinternacionais/conteudo-banners-1/enccla/restrito/manual-colaboracao-premiada-jan14.pdf.> Acesso em: 25 maio. 2018.

NUCCI, Guilherme de Souza. Manual de direito penal. 7. ed. São Paulo: Revista dos Tribunais, 2011.

PARANAGUÁ, Rafael. Origem da delação premiada e suas influências no ordenamento jurídico brasileiro. Brasília, DF, 22 de novembro de 2013. Não paginado. Disponível em: $<$ https://www.advcorrespondente.adv.br/origem-da-delacao-premiada-e-suas-influenciasordenamento-juridico-brasileiro/>. Acesso em: 24 abr. 2018.

SANTOS, Marcos Paulo Dutra. Colaboração (delação) Premiada. Salvador: Jus Podium, 2017.

SILVA, Eder Nunes. O instituto da colaboração premiada no combate ao crime organizado. 2016. Não paginado. Disponível em: <https://edertrombelli.jusbrasil.com.br/artigos/356215803/o-instituto-da-colaboracaopremiada-no-combate-ao-crime-organizado>. Acesso em: 26 jul. 2018.

SILVA, Márcio Alberto Gomes. Organizações Criminosas: Uma Análise Jurídica e Pragmática da Lei 12.850/13. Rio de Janeiro: Lumen Juris, 2017.

SOUTHWELL, David. A história do crime organizado. São Paulo: Escala, 2013.

VASCONCELlOS, Vicente Gomes de. Colaboração Premiada no Processo Penal. São Paulo: Editora Revista dos Tribunais, 2017. 